年次大会・抄紙セッションA

ベルボンドフォーマー・シュープレスの操業経験

本州製紙株式会社釧路工場抄造部 須 藤 記 生

\title{
Operating Experience of Bel-bond Former and Shoe Press
}

\author{
Norio Sudoh \\ Honshu Paper Co. Ltd., Kushiro Mill
}

\begin{abstract}
L-1 machine started up in 1974 at kushiro Mill Honshu Paper Co., Ltd to correspond to increase in demand of Liner board.

We will report the operating experience of Bel bond Former installed in 1984 and E.N.P in 1991 in L-1 machine.

This in stallation provided high productivity for us.
\end{abstract}

\section{1.はじめに}

釧路工場 L-1 マシンは，昭和 49 年に段ボール原紙 の需要增加に対応し, 釧路工場 4 台目の抄紙機として 稼働した。その後, 釧路工場の他の抄紙機が洋紙に転 換するなか，一環して段ボール原紙を生産し今日に至 つている。今回は, L-1 マシンの昭和 59 年に増設し たベルボンドフォーマーと平成 3 年に設置したエクス テンデットニッププレスの操業概要と経験について報 告する。

\section{2. 工 場 概 要}

当工場は, 昭和 34 年 9 月, 国産初の段ボール原紙 専抄工場として稼勳。その後, 国内外の激動に対応し て拡大・転換を図り, 洋紙・板紙の両部門を備えたバ ランスの取れた工場となっている。現状の工場概要は 次の通りである。

(1) 工場所在地；北海道釧路市

(2) 従業員数; 約 520 名

(3) 敷地面積; 200 万 $\mathrm{m}^{2}$ (約 63 万坪)

(4) 生産品種; 印刷用紙・新聞用紙・段ボール原 紙

(5) 生産 設 備; 抄紙機 4 台（洋紙 3 台，板紙 1 台)

$\mathrm{KP}$ 蒸解設備: 連続蒸解 4 系列 $\mathrm{KP}$ 晒 設 備: 多段漂白 3 系列 抄取 1 系列

機械パルプ設備 : 2 系列
古紙パルプ設備：2 系列

ボイラー：回収ボイラー3 基, 石 炭ボイラー 3 基, 重油 ボイラー 3 基

タービン発電機 $: 6$ 基

６）年間生産量；洋紙 28 万 ton 板紙 42 万 ton 計 70 万 ton

\section{3. $\mathbf{L}-1$ マシン設備概要}

\section{1 一般仕様}

・生産品種: Kライナー, 撥水・耐水ライナー, 高リングクラッシュK ライナーほか

・米 坪 : $140 \mathrm{~g} \sim 320 \mathrm{~g}$

・常用運転抄速 : $750 \mathrm{~m} / \mathrm{min}$

・ワイヤー幅: $7,100 \mathrm{~mm}$

・リール最大紙幅 $: 6,700 \mathrm{~mm}$

・フォーマータイプ: フォードリニアタイプ (ベルボ ンドフォーマー2 基) 3 層抄

3.2 原料・白水系

・スクリーン：

1 層 三菱バード型セントリスクリーン 2 基

2 層“ " " 1 基

3 層 " " 1 基

・クリーナー: 1 次 $~ 5$ 次

3.3 抄 紙 機

・ヘッドボックス：

1 層 エアークッションストックインレット 
$2 \cdot 3$ 層 三菱一ベロイトシンチャンネル型 コンバーフローシートヘッドボッ クス

・ワイヤーパート：フォードリニア $+\mathrm{BBF}+\mathrm{BBF}$

・プレスパート：バイニッププレス $+3 \mathrm{P}+\mathrm{ENP}+$ $\mathrm{SM}$

・ドライパート：PD 65 本 PV ロール 37 基 BS

・カレンダー : 2 基 三菱一ベロイトオープンカレン ダー

・リ - ル：三菱ーベロイト式

・ワインダー：2 ドラム三菱一べロイト式ワインダー

・仕上設 備：全自動設備（印字・テーピング・バン デイング・搬送)

\section{4. ワイヤーパート}

\section{1 設 備 概 要}

段ボール用ライナー原紙の場合, 特に紙の強度適性 を求められるため, 多層抄が一般的であり L-1 マシ ンも多層抄構成となっている。 L-1 マシンの設置当初

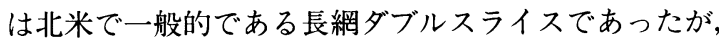
多層抄構成による生産性の向上及びューザーニーズに 適応した品質向上を目指し，昭和 59 年に 3 層抄にす ベくベルボンドフォーマーを設置した。次に設備の概 要と操業性等について述べる。

\section{2 ヘッドボックス}

昭和 59 年に 2 層抄から 3 層抄に変更と同時に, 2 ・ 3 層用ヘッドボックスをシンチャンネル型コンバーフ ローヘッドボックスに変更した。

導入のポイントとしては, 小型で地合分散性が良く, 広い流量変化に対応するへッドボックスが必要なため, 多層抄及び板紙用ヘッドボックスとして実績の高いシ ンチャンネル型コンバーフローとした。このへッドボ ックスの特徴として, ヘッドボックス内部にある 3 枚 のコンバーフローシートが流量の変化に対して分散 性・整流効果の維持が図れる形となっており，フロー シートの取り扱いが重要である。プラスチック製シー トのため, 破損や污れがつきやすく, マシン停止ごと
の確認・掃除が必要不可欠である。多少の先端欠け・ 污れにより“ジェット割れ”と呼ばれる突出ムラから の地合ムラが発生する。

また, へッドボックス底部への粕付きの問題から， ヘッドボックス高さの変更を実施して対応しているが, 地合等への悪影響を及ぼすため, 解決に向け努力中で ある。

\section{3 ベルボンドフォーマー（BBF）}

ベボンドフォーマーは，CIVB（カーブドインバー テッドバキュームボックス) と前側にオートスライス を付属した脱水機構をもっている。本体は 3 室（オー トスライス・\#1サクションボックス・\#2 サクション ボックス）の真空室とセラスライドによって構成され ている

脱水の基本原理は，トップワイヤーとボトムワイヤ 一に挟まれたシートはリードインロール下のアンダー ワイヤーホイルの曲面による遠心力とワイヤーテンシ ヨンによる絞り作用によってシート中の水分が外側へ 押し出される。

オートスライスはこれらの押し出された水をオート スライス内の真空及びマシンスピードを利用して搔き 込み，次にシートはCIVBの曲面目板を通るカーブ したワイヤー間でバキュームにより上方に脱水され， 紙層が形成される。特にライナー原紙のように米坪範

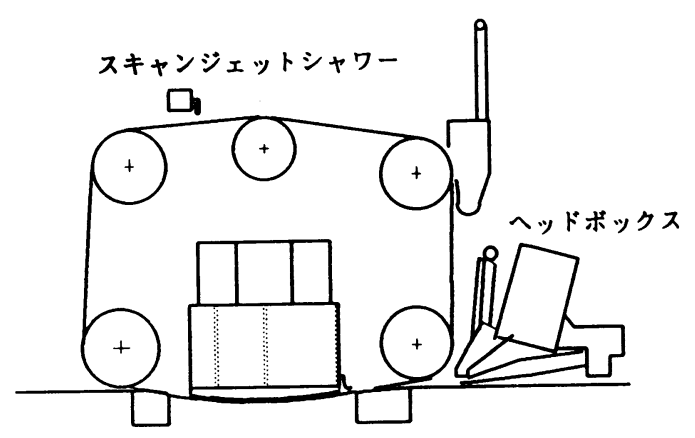

図 $1 \mathrm{BBF}$

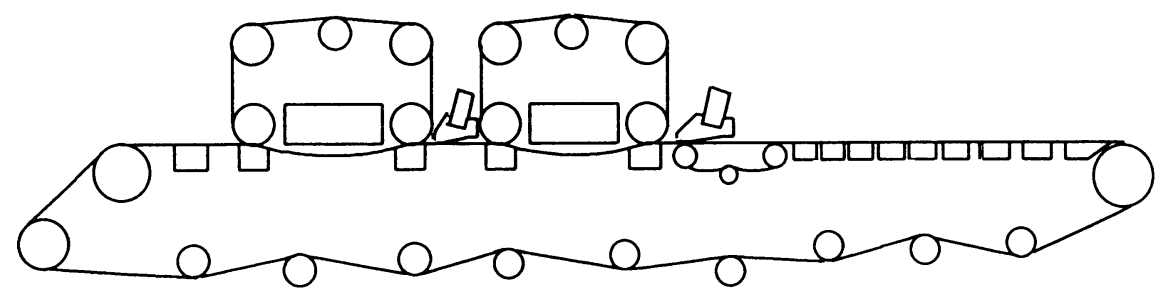

図 2 ワイヤーパート 
囲が広い場合には，各ゾーンでの脱水比率が地合形成 の上に大きな要素をしめており，各バキューム・リー ドインロール挟み角・UWF (アンダーワイヤーホイ ル）位置などの操作が重要なポイントである。

一方，脱水能力維持のためには，各層に適したワイ ヤーの選定が重要である。

《選定の必要ポイント》

(1) 寸法安定性 $\rightarrow$ 幅方向脱水么ラ防止

(2) リテンション ススート部・スロット穴のスケ 一ル防止

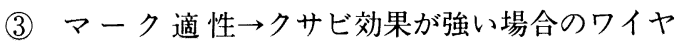
ーマーク防止

以上のように, BBF は汎用性の高いフォーマーで あるが，地合形成維持のためには適合した条件設定を 繰り返し実施することが必要である。この条件のなか で各層のジェットワイヤー比と BBF の入口濃度が最 も重要であり, ジェットワイヤー比は着地時の紙層形 成具合により変更が必要である。また, BBFの入口 濃度は生産べースと脱水能力のバランスで地合が大き く変化するため，これを考慮した濃度設定にすること が必要である。ワイヤ一の污れ防止もまた地合の形成 の安定のためには必要不可欠であるが, 過剩な洗浄は ワイヤーからのミスト飛びを増加させ, 機器への粕付 着による紙切れを誘発する。この対策として, BBF でのインロール化を進め, スキャンジェットシャワー によるアウトサイドから洗浄を強化している。

その他, 設置当初 2.3 層ジェット着地点に, サクシ ヨンボックスを設置していたが, 着地ジェットの衝撃 力により振動が発生し, 地合に影響が出たため, サク ションボックスを撤去し, 衝撃力を緩和するフォイル アレンジを実施している。

\section{4 その他特徵点}

ウェットシートでの平滑性向上, クーチロールでの 脱水強化を目的に, ランプブレーカーロールを設置し ていたが，ロールへの粕付着・粕飛びによる紙切れが 発生しており，各種対策をするも根本解決に至らず撤 去している。取り外し後, 紙切れ減少・強度アップ・ 抄幅拡大のメリットがでている。また，心配された品 質・操業への影響も小さくなっている。

\section{ENP}

ライナ一の品質向上とコストダウンを目的に，平成 3 年に $4 \mathrm{P} に$ ENP (Extended Nip Press) が導入さ れた。下記に，この設備概要及び効果を最大限に発揮 させるための事前検討とその結果・問題点等について 述べる。

\subsection{ENP 設置前の検討と設置直後の状況}

\section{(1) 通 紙 性}

当初キャリアでの通紙を検討したが，ENPの構造 上の問題から，エア一方式で実施。3 P ENP 間の距 離が近く, シートの飛びも問題なく操業している。

(2) 断紙時のトラブル

設置当初， $3 \mathrm{P}$ から ENP 間で紙切れ時に湿紙飛び 込みによる要具損傷のトラブルが発生した。原因とし ては, シートカッ夕ーによに飛び込み防止が可能と判 断していたが，逆にカッティングできず，カッタ一部 に湿紙が留まり，飛び込んだと推定される。

対策として，図3のように上部ワットデフレクター 取り付け・光電管取り付けによりトラブル防止を実施 した。

(3) スチーリング対策

トップフェルトへのスチーリング対策として，出口 フェルトロールのグルーブド化及び立ち上がり部に吹 き落としエアーパイプとクッションタンクの設置を行 ったが，ENP入口水分が低いこともあり，スチーリ ングのトラブルは発生していない。

(4) 油漏 れ

設置当初，ENP シュー潤滑オイルの消費量が増え， 約 $200 \mathrm{l} /$ 日にもなったことがあった。オイルの消費量 はニップ出口にあるスクレーパーの当たり具合によっ て増減をする。これまでスクレーパーの長さ・形状変 更・ブランケットサポート用ローラーの変更・ブラン ケットテンション管理の変更を経て, 現在は 1 日の消
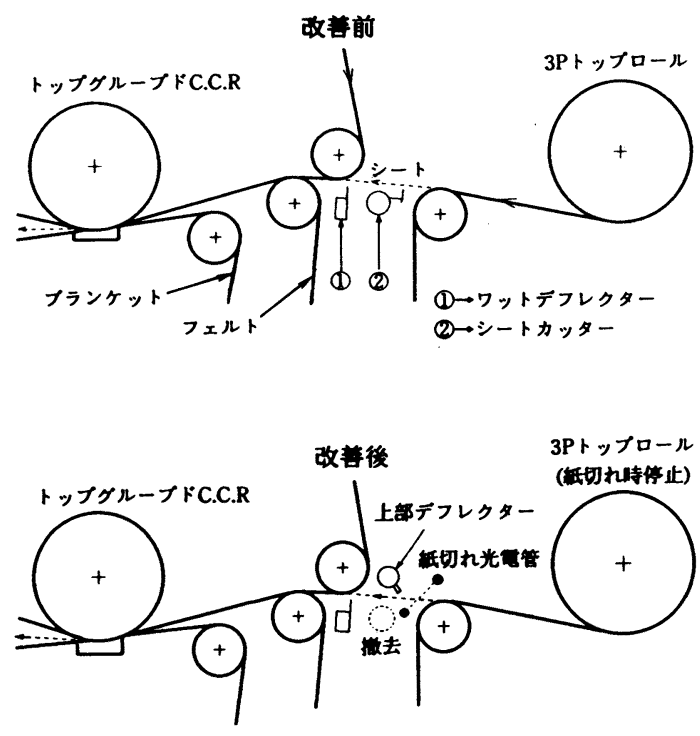

図 3 ENP 断紙対策 


須藤記生

費量は $20 \sim 50 l$ 程度まで減少している。最近の ENP は更に改善され，大きく減少しているはずである。

(5) 要具の品質

ENP 用のフェルトは高ニップのため, 通常のフェ ルト組成では脱毛が進みフェルトマーク等により製品 の外観に影響度が高く脱毛・肌対策が必要であり, 要 具メーカーとのタイアップが求められる。また，ブラ ンケットは摩耗による強度ダウン及び伸びにより寿命 がきまっており，現在摩耗防止対策の検討を実施して いる。

\section{2 設置後の効果}

(1) 紙力剤の減少

当初の期待通り, 紙力剤は設置前後で表 1 のように 前年度の約 $61 \%$ になっている。

(2) 蒸気原単位向上

設置後は, ドライヤー入口水分の減少により乾燥用 の蒸気使用量が対前年の $78 \%$ になっている。

\section{（3）增 速}

ドライヤーの乾燥能力により抄速の抑えられていた 銘柄について, 表 2 のように改造前後の抄速で比較す ると増速が可能となっている。

(4) 紙切れ減少

プレス出口水分の低下に伴う紙匹強度アップによる 減少だけではなく, 紙力剤減少による系内の污れ防止 が進み, 粕等の紙切れ減少の効果も高く, 設置前後で の紙切れ回数はほぼ半減している。

(5) 品質向上

プレス出口水分の低下とともに, 幅方向の水分のバ ラッキも小さくなり, 表 3 に示す通り設置後バラッキ は約 $82 \%$ となっている。これにより，最終製品の仕 上りも大幅に改善されている。

（6）印刷適性

平滑度及び透気度が上昇し，インキの着肉が良化し ている。

\section{6. おわりに}

以上, 釧路工場 $\mathrm{L}-1$ マシンの設備概要とベルボン ドフォーマー・シュープレスの操業経験について述べ た。

ベルボンドフォーマーは操業方法により, 地合等の 品質への影響度が高い。今後もユーザーのニーズにこ たえた安定した品質維持に努め, 更なる改善を目指し 操業して行く。
表 1 各原単位の向上

（設置前を 100 とする）

\begin{tabular}{l|c}
\hline & 設置後 \\
\hline 紙力剤コスト & 61 \\
\hline 蒸気原単位 & 78 \\
\hline 電力原単位 & 97 \\
\hline
\end{tabular}

表 2 米坪別最高抄速 (設置前を 100 とする)

\begin{tabular}{c|c}
\hline 米坪 & 設置後 \\
\hline $200 \mathrm{~g} / \mathrm{m}^{2}$ & 102 \\
\hline $220 \mathrm{~g} / \mathrm{m}^{2}$ & 102 \\
\hline $280 \mathrm{~g} / \mathrm{m}^{2}$ & 113 \\
\hline $320 \mathrm{~g} / \mathrm{m}^{2}$ & 110 \\
\hline
\end{tabular}

表 3 水分バラツキ平均 (設置前を 100 とする)

\begin{tabular}{l|c}
\hline 米坪 & 設置後 \\
\hline $180 \mathrm{~g} / \mathrm{m}^{2}$ & 70 \\
\hline $220 \mathrm{~g} / \mathrm{m}^{2}$ & 87 \\
\hline $280 \mathrm{~g} / \mathrm{m}^{2}$ & 85 \\
\hline 平 均 & 82 \\
\hline
\end{tabular}

シュープレスについての今後の課題としては, 操業 性と品質の維持を保ちつつ要具の延命をいかに図って いくかがあり, 要具メーカーと共にフェルトの脱毛防 止及びブランケットの摩耗による伸びの対策を検討し て行く。また，油漏れの減少のため, 設備・管理・要 具の面から改善を図っていく考えである。

L-1 マシンは, わが国でも有数の高日産マシンとし て, 多くの改善を重ね最大生産能力としては $220 \mathrm{t} /$ $\mathrm{D} / \mathrm{m}$ を超える高性能な抄紙機となった。これらの改 善のうち BBF 設置とシュープレスが大きなウェート をしめており，やや古い経験になってしまったが，今 回まとめてみたこの報告が少しでも御参考になり，お 役に立てば幸いである。 